\title{
Causes and consequences of falls in Parkinson disease patients in a prospective study
}

\section{Przyczyny i konsekwencje upadków w chorobie Parkinsona - badanie prospektywne}

\author{
Monika Rudzińska', Sylwia Bukowczan', Joanna Stożek², Katarzyna Zajdel', Elżbieta Mirek², Wiesław Chwała², \\ Magdalena Wójicik-Pędziwiatr', Krzysztof Banaszkiewicz', Andrzej Szczudlik' \\ 'Department of Neurology, Jagiellonian University Medical College, Krakow, Poland \\ 2Department of Clinical Rehabilitation, University School of Physical Education, Krakow, Poland \\ ${ }^{3}$ Institute of Otolaryngology, Department of Otolaryngology, Jagiellonian University Medical College, Krakow, Poland
}

Neurologia i Neurochirurgia Polska 2013; 47, 5: 423-430

DOI: 10.5114/ninp.2013.38222

\begin{abstract}
Background and purpose: Falls are common events in Parkinson disease (PD) but only a few prospective studies have focused on causes and consequences of falls in PD patients. The aim of the study was prospective analysis of direct causes and consequences of falls in PD patients in comparison to the control group.

Material and methods: One hundred PD patients and 55 age-matched controls were enrolled in the study. The diagnostic workup in all patients included neurological examination, Unified Parkinson's Disease Rating Scale, magnetic resonance imaging, electroencephalography, ultrasonography, otolaryngological, ophthalmological and autonomic function examination. During 12 months of follow-up, falls were registered in both groups, direct causes were classified according to the St. Louis and Olanow classification, and consequences were established.

Results: Falls occurred in 54\% of PD patients and in $18 \%$ of control subjects. Analysis of direct causes of falls revealed that sudden falls were the most common $(31 \%)$, followed by episodes of freezing and festination (19.6\%), neurological and sensory disturbances (mostly vertigo) (12\%), environmental factors $(12 \%)$, postural instability $(11 \%)$, orthostatic hypotension (4\%), and severe dyskinesia (3.6\%); $6.19 \%$ of falls were unclassified; $22 \%$ of patients had the same etiolo-
\end{abstract}

\section{Streszczenie}

Wstęp i cel pracy: Upadki są częstymi objawami choroby Parkinsona (ChP). Dotychczas jednak tylko w kilku badaniach oceniano przyczyny i konsekwencje upadków w ChP.

Celem badania była prospektywna analiza przyczyn bezpośrednich oraz konsekwencji upadków u pacjentów z $\mathrm{ChP}$ w porównaniu z grupą kontrolną.

Materiał i metody: Do badania zostało włączonych 100 chorych na $\mathrm{ChP}$ oraz 55 dobranych pod względem wieku osób z grupy kontrolnej. U wszystkich chorych przeprowadzono badanie neurologiczne, ocenę za pomocą Unified Parkinson's Disease Rating Scale, badanie za pomocą rezonansu magnetycznego, elektroencefalografię i ultrasonografię, badanie otolaryngologiczne i okulistyczne oraz badanie czynności autonomicznych. Podczas 12-miesięcznej obserwacji upadki rejestrowano w obu badanych grupach. Przyczyny bezpośrednie upadków podzielono zgodnie z klasyfikacją St. Louis i Olanowa, określano także konsekwencje upadków.

Wyniki: Upadki wystąiły u 54\% chorych na ChP i $18 \%$ osób z grupy kontrolnej. Najczęstsze były upadki nagłe (31\%), następnie epizody zamrożeń i dreptania $(19,6 \%)$, zaburzenia neurologiczne i czuciowe (zawroty głowy) (12\%), czynniki zewnętrzne $(12 \%)$, niestabilność postawy $(11 \%)$, niedociśnienie ortostatyczne (4\%), nasilone dyskinezy (3,6\%). Upadki niesklasyfikowane stanowiły $6,19 \%$. U $22 \%$ chorych etio-

Correspondence address: dr n. med. Magdalena Wójicik-Pędziwiatr, Department of Neurology, Jagiellonian University Medical College, 3 Botaniczna St, 31-503 Krakow, Poland, e-mail: stokrotka283@tlen.pl

Received: 2.08.2012; accepted: 7.01.2013 
gy of subsequent falls. In PD patients, intrinsic factors were dominant, whereas in the control group intrinsic and extrinsic factors occurred with the same frequency. Every third fall intensified fear of walking. $34 \%$ of falls caused injuries; among them bruises of body parts other than the head were most frequent.

Conclusions: Intrinsic factors are the most common causes of falls in PD. Every third fall intensifies fear of walking and causes injuries.

Key words: Parkinson disease, falls, risk factors.

\section{Introduction}

Falls are common events in the older age population, causing medical and economic problems, often leading to short-term or permanent disability. The consequences of falls, such as injuries or bone fractures, are the sixth leading causes of death in the elderly [1]. During a oneyear observation period, at least one fall occurred in $33 \%$ of people over the age of 65 who live in the community [1]. Despite the various coexisting disorders potentially related to falls, such as dizziness (vertigo), orthostatic hypotension, syncope or vision impairment, $50 \%$ of falls in elderly people are caused by environmental factors and only $30 \%$ of falls are caused by factors related to disorders [2]. The study showed, however, that the older the individual, the higher the risk of falls caused by intrinsic factors [3].

In Parkinson disease (PD) patients, falls occur more frequently than in the general elderly population. They were reported in 38-68\% of patients with PD [4-7], constituting one of the most important cause of morbidity and mortality [8-10]. It was demonstrated that recurrent falls often cause traumatic consequences [11-13] and shorten the duration of life in PD patients by 7 years [8-10].

The causes of falls can be classified in different ways. The multidisciplinary team of researchers from St. Louis for the purpose of the Older Adult Service and Information System study differentiated falls as caused by intrinsic factors, extrinsic factors and by non-bipedal stance $[2,4]$. Using the above classification, intrinsic factors are considered the cause of $70 \%$ of all falls in PD.

The specific direct causes of falls in PD patients were classified by Olanow et al. [14] as follows: postural instability, episodes of freezing and festination, levodopainduced dyskinesia, symptomatic orthostatic hypotension, coexistent neurologic disorders, other medical disorders, and local environmental factors. Until now, this logia kolejnych upadków była jednakowa. U chorych na $\mathrm{ChP}$ dominowały czynniki wewnętrzne, a w grupie kontrolnej częstości czynników wewnętrznych i zewnętrznych były podobne. Co trzeci upadek nasilał lęk przed chodzeniem, 34\% upadków powodowało obrażenia, najczęściej stłuczenia. Wnioski: Czynniki wewnętrzne są najczęstszymi przyczynami upadków w ChP. Co trzeci upadek nasila lęk przed chodzeniem oraz powoduje obrażenia.

Słowa kluczowe: choroba Parkinsona, upadki, czynniki ryzyka.

classification has not been used however in any prospective published study of falls in PD patients.

The aim of the study was to assess the causes and consequences of falls in PD in comparison to a control group in a prospective study.

\section{Material and methods}

\section{Subjects}

Participants were recruited from the Movement Disorders Clinic of the Department of Neurology, Jagiellonian University Medical College in Krakow. Participation in the study was offered to all consecutive patients who visited the clinic between February 2004 and February 2005 . Inclusion criteria were as follows: diagnosis of PD established according to UK PD Society Brain Bank criteria [15] at least 12 months prior to inclusion in the study, Hoehn and Yahr stage II-IV, disease duration of at least 3 years and sustained, lasting longer than one year, good response to levodopa therapy.

Exclusion criteria were: severe gait disability which made the person unable to walk unassisted, disorders other than PD which might have caused weakness or instability (stroke or myocardial infarction less than 3 months prior to the inclusion, severe dementia, severe hepatic or renal insufficiency, cancer, ankylosing spondylitis, severe coxarthrosis), a history of orthopedic surgery of either hip or knee causing gait difficulties, other chronic disorders of the osteoarticular system which would cause mobility limitation, epilepsy, and chronic disorders of the ear causing balance disturbances.

Age-matched ( \pm 2 years) controls were recruited from the persons accompanying the patient, excluding their caregivers, or others visiting the in-patients of the Neurology Department. The exclusion criteria were the same as for patients, with the additional exclusion of any sign of parkinsonism in neurological examination. 
This study was approved by the local ethics committee and all patients and controls gave their written informed consent to participate in this study.

\section{Methods}

The study was conducted in a prospective manner. After giving consent, participants (volunteers, PD patients or their caregivers) were interviewed by the same investigator (S.B.) about incidence, circumstances and consequences of falls in the previous year. They were briefly educated according to possible causes of falls and obliged to report the occurrence and circumstances of each fall within 7 days following the event during the one-year follow-up in a special diary and/or by phone call. Patient were appointed to visit the clinic quarterly and encouraged to make an additional visit or phone call in case of severe consequences of a fall, increased severity of PD symptoms or other medical events recognized as an emergency. In case of difficulties in carrying out an interview with the patient caused by cognitive impairment, the data about falls were collected from his caregivers.

At the entry of the study (baseline) all patients underwent a multidisciplinary assessment for the evaluation of non-parkinsonian causes of falls including: neurological, laryngological and ophthalmologic examination, electroencephalography (EEG), standard 12-lead electrocardiogram (ECG), ultrasonographic examination of the carotid and vertebral arteries, electronystagmographic evaluation of vestibular function where response asymmetry of $20 \%$ or more was considered abnormal, cognitive function assessment, X-ray of the cervical spine, magnetic resonance imaging (MRI) of the brain, and evaluation of the cardiovascular system by use of the Biopac system [16]. Patients were also asked about details concerning the course of the disease (disease duration, medication, coexisting symptoms, occurrence of motor fluctuations and dyskinesia), other neurological disorders (such as confusion, dementia, depression, or transient ischaemic attacks), cardiovascular diseases, and other symptoms and disorders as well as about all drugs taken during the last 5 years. The interview was followed by a physical examination, which included evaluation of gait disturbances typical for PD (freezing of gait, festination, hesitations). At the baseline visit, the severity of the disease was assessed using the Unified Parkinson's Disease Rating Scale (UPDRS) and the Hoehn and Yahr scale, the impairment of activities of daily living by the Schwab and England scale, cognitive dysfunction by the Mini-Mental State Examination
Table 1. Causes of falls according to Olanow et al. [14]

\begin{tabular}{|l|}
\hline 1. Postural instability \\
\hline 2. Episodes of freezing and festinations \\
\hline 3. Intensified dyskinesia \\
\hline 4. Sudden falls \\
\hline $\begin{array}{l}\text { 5. Autonomic system disorders (orthostatic hypotension, } \\
\text { neurocardiogenic syncope, postural orthostatic tachycardia } \\
\text { syndrome) }\end{array}$ \\
\hline $\begin{array}{l}\text { 6. Neurological and sensory disturbances (muscle weakness } \\
\text { of lower limbs, deep sensibility impairment, epileptic seizure, } \\
\text { cognitive impairment, visual impairment, balance impairment) }\end{array}$ \\
\hline 7. Cardiovascular diseases \\
\hline 8. Drugs \\
\hline 9. Environmental factors \\
\hline
\end{tabular}

(MMSE) and depression by the Hamilton scale. Patients who experienced motor fluctuations were examined while they were in their 'on' state.

A fall was defined as an unexpected event where the person inadvertently came to rest on the ground or other lower level [17]. The causes of falls were recognized according to two different classifications. The first one was the St. Louis classification that distinguished: (1) falls related to extrinsic factors (slip, trip, displaced center of gravity); (2) falls caused by intrinsic factors (mobility systems failure, impaired balance, sensory impairment, cognitive impairment); (3) non-bipedal falls (self-generated falls, support failure); (4) non-classifiable falls.

The St. Louis classification is a geriatric tool for classification of falls among elderly persons. It was applied in order to enable the comparison of causes of falls between PD patients and controls.

The second classification of causes of falls was carried out according to Olanow et al. [14] (Table 1). By the time when the methodology of the study was being established, it was the only tool for classification of falls in PD patients. If the patient or the caregiver reported a fall which occurred when patient changed position (e.g., during getting out of a chair or turning, or bending over) the fall was then categorized as due to postural instability. A sudden fall (toppling fall) was recognized when a patient characterized it as "falling like a log" with no apparent cause. The causes of falls considered as environmental were those related to inappropriate footwear or assistive devices for walking (walkers, canes etc.) or domestic environmental hazards (slippery surfaces, poor lighting, unsafe stairways, etc.).

The cause of each fall was defined by a physician based on knowledge of the patient's state (obtained from 
interview, neurological examination as well as additional tests) and on his or her description of the circumstances in which the fall occurred. The incidence of each cause of fall was a ratio of the number of falls caused by a single cause to the total number of falls.

The consequences of falls were analyzed according to three categories: (a) subjective consequences (presence or worsening of the fear of falling during walking, restriction of physical activity following the fall); (b) objective consequences such as: hospitalization, necessity to visit a surgeon, long-term immobilization of the limb, or requirement of bed rest; and (c) objective consequences such as visible body injuries as a result of the fall, e.g. injury of the head or other part of the body, fracture, wound, joint dislocation and others.

Each person from the control group underwent the neurological examination. Falls, their causes (according to the St. Louis classification) and consequences were reported in the control group, the same as in the group of patients at 1-year follow-up.

\section{Statistical analysis}

Categorical variables of patients and controls were statistically assessed for association using the $\chi^{2}$ test and Fisher exact test. Normally distributed continuous variables were assessed using the $t$-test for independent samples. The Mann-Whitney $U$-test was used for variables that were not normally distributed. A $p$-value $<0.05$ was considered statistically significant.

\section{Results}

One hundred out of 106 included PD patients completed the one-year prospective study and their results

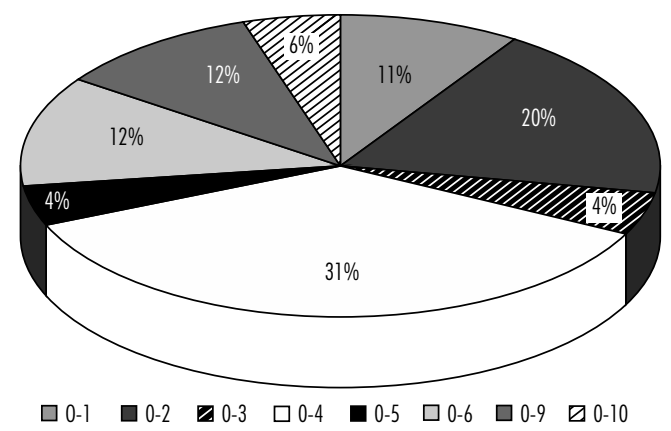

The causes of falls: O-1: impairment of postural reflexes, O-2: the episodes of freezing and festination, O-3: severe dyskinesia, O-4: sudden falls, O-5: autonomic system disorders, O-6: neurological and sensory disturbances, O-7: cardiovascular diseases, O-8: drugs, O-9: environmental factors, $0-10$ : unclassified causes

Fig. 1. Causes of falls in Parkinson disease according to Olanow et al. classification (2001) were analyzed. Three patients died and another three did not contact the clinic during the study as agreed at the baseline visit. One of 56 involved volunteers died during the study, so the data from the rest of 55 controls were analyzed.

Patients and control groups did not differ in terms of age (67.2 vs. 65.5 years, $p=0.25$ ) and gender (women: $50.0 \%$ vs. $65.5 \%, p=0.065$ ). The mean PD duration was $6.2 \pm 3.4$ years, mean severity of disease on the Hoehn and Yahr scale was $2.75 \pm 0.65$, the UPDRS mean total score was $48.90 \pm 13.70$, the UPDRS part III average score was $32.16 \pm 13.84$, the mean of the Schwab-England scale was $79.93 \pm 13.70 \%$, and the mean daily dose of levodopa was $736.6 \pm 336.8 \mathrm{mg}$. The patients obtained a mean score of 27.46 (range 1730 ) in the MMSE and a score of 9.09 (range 0-32) on the Hamilton Scale.

During one year of observation, at least one fall occurred in $54(54 \%)$ PD patients and in $10(18 \%)$ control subjects $(p=0.001)$. Thirty-four patients reported 1-3 falls, 6 patients had 4-5 falls, 5 patients reported 6-8 falls and 9 patients had more than 8 falls. The other three patients fell very frequently, up to 20 times a day, making it difficult to accurately determine the number of falls. Excluding these patients, a total of 194 falls were reported by 51 patients and 45 falls in 10 subjects of the control group.

The most frequently reported cause of falls classified according to Olanow et al. [14] was sudden falls, constituting $31.4 \%$ of all falls. Freezing and festination episodes (19.6\%) were the second most common causes of falls. They were followed by neurological disorders (12.4\%), mostly dizziness or vertigo (91.3\%) and weakness of leg muscles (8.7\%). Also contributing to falls were: environmental factors (11.9\%), postural instability $(10.2 \%)$, orthostatic hypotension (4.1\%), and severe dyskinesia (3.6\%). Another $6.2 \%$ of falls could not be classified. There were no falls caused by drugs or cardiovascular diseases (Fig. 1).

According to the St. Louis classification system, $23(11.8 \%)$ falls in PD patients were identified as caused by extrinsic factors, 84 (43.3\%) by intrinsic factors, and $16(8.2 \%)$ by non-bipedal stance. 71 (36.6\%) falls could not be classified in any of the above-mentioned categories (Fig. 2). In the control group, extrinsic factors caused $16(35.6 \%)$ falls, intrinsic factors were responsible for 15 falls $(33.3 \%)$, and non-bipedal stance contributed to $2(4.4 \%)$ falls. The causes of $12(26.7 \%)$ falls were unclassified. Falls caused by extrinsic factors were significantly more frequent in the control group 
compared to the patient group (35.6\% vs. $11.8 \%$, $p=0.0001$ ) (Fig. 2).

Among the patients who fell more than once during the prospective one-year observation period, only $12(22.2 \%)$ had the same etiology of subsequent falls. In most of these cases there were sudden falls, neurological symptoms, and freezing and festination episodes. Twenty-three patients who fell at least two times $(42.6 \%$ of fallers) had various direct causes of falls. In 14 subjects there were two kinds of direct causes of falls, and in 9 patients there were three or more. The three patients who fell extremely frequently, up to twenty times a day, and could not determine precisely the number of falls, had probably the same cause of fall. All of them claimed that they fell at least several times a day, and all falls were directly preceded by episodes of freezing.

The most common consequence of falls, in both patients and controls, was a fear of walking. The fear was induced or aggravated by $74(38.1 \%)$ falls in PD patients and in $17(37.8 \%)$ falls in controls. Additionally, 7 (3.6\%) falls in PD patients and 9 (20\%) falls in controls caused restrictions of motor activity for some period of time, without the awareness of feeling anxiety. Analysis of the objective consequences of falls revealed significantly more frequent complications of falls in patients than in the control group. Two (1.0\%) of 194 analyzed falls in PD patients were the cause of hospitalization, 7 (3.6\%) falls forced them to visit a surgeon and one resulted in long-term immobilization of the patient at home. There was no case of hospitalization or even visit to a physician because of fall in controls. Patients also revealed more complications such as injuries of the body than controls. Four falls $(2.1 \%)$ in PD patients resulted in fractures of the limbs, 3 (1.6\%) falls ended in joint dislocation, $6(3.1 \%)$ falls contributed to superficial contusions of head or face, and 35 (18.0\%) caused contusions of other parts of the body. Nineteen (9.8\%) falls resulted in sustained superficial wounds. There was no case of injury because of a fall in controls (Fig. 3).

\section{Discussion}

The study showed that sudden falls, freezing of gait and neurological disturbances classified according to Olanow et al. [14] were the most common direct causes of falls in PD patients. Until recently, no single prospective study analyzing causes of falls using this classification was published. However, this classification was used in two Polish retrospective studies $[17,18]$. In

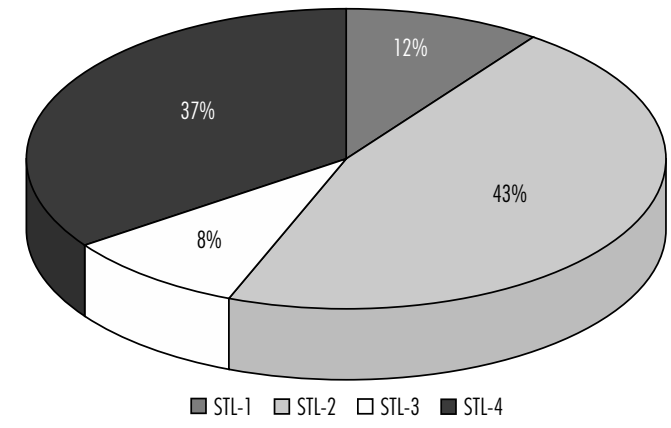

The causes of falls: STL-1: extrinsic factors, STL-2: intrinsic factors, STL-3: non-bipedal stance, STL-4: unclassified factors

Fig. 2. Causes of falls in Parkinson disease according to St. Lovis classifi cation

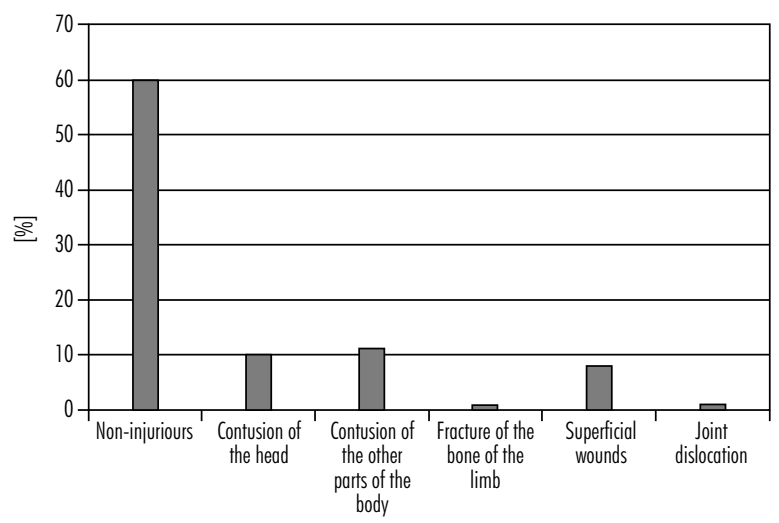

Fig. 3. Injuries resulting from falls

the study by Michałowska et al. [18] the most common causes of falls were sudden falls $(32 \%)$, postural instability $(32 \%)$ and freezing or festination (16\%) but these percentages represent the patients who fell because of a specific cause, not the percentage of all falls as in our study. The second Polish paper analyzed retrospectively falls in the same group of patients and controls as in this prospective study [17]. Analyzing the causes of falls based on anamnesis, it was revealed that the most frequent causes of falls were environmental factors (32.3\%). The second most common were sudden falls (28.3\%), then postural instability (11.9\%) and freezing episodes $(10.5 \%)$. The remaining causes contributed to falls only in a small proportion, and in $11 \%$ of falls they could not be classified [17].

Comparing the results of our prospective and retrospective study, it can be assumed that sudden falls, freezing episodes as well as postural instability as direct causes of falls either in retrospective or prospective studies 
occur at the same frequency. In the retrospective study, the environmental factors were surprisingly often reported as causes of falls - perhaps patients remember falls which were caused by the presence of some kind of obstacle. In the prospective study, the number of unclassified falls was two times lower than in the retrospective study.

The high rate (more than $30 \%$ ) of sudden falls in PD patients is surprising. Sudden (toppling) falls occur unexpectedly, without any preceding symptoms; the patient falls "like a log". So far it has not been accurately established what is the cause of this type of fall. In one study, the relationship of sudden falls with epileptic discharges was suggested [19]. All patients in our study underwent a precise interview with regard to seizures disorders and no such events were recognized. EEG examinations were also carried out in all patients, and did not reveal epileptic discharges in any patient. Patients definitely denied the presence of any symptoms prior to the falls recognized as sudden falls. Such falls have limited possibilities of prevention, because they are completely unpredictable.

Freezing and festination episodes as the cause of $20 \%$ of falls are not controversial. Freezing is a quite common symptom of advanced PD and naturally generates falls. In the study of Gray and Hildebrand [20], freezing of gait episodes were related to $36 \%$ of falls. That slightly higher percentage in comparison to our study may be associated with the fact that in this study the questionnaires about falls were filled in by the patients and it was easier for them to identify a freezing episode than e.g. a sudden fall which was not characterized by any preceding symptoms. It is likely that episodes of freezing suggested to the patient the cause of the fall, though such an episode did not necessarily directly precede or cause the falls. In any case, both studies confirm that freezing episodes are one of the most important direct causes of falls.

Among the neurological and sensory disturbances, which in our study were the third leading cause of falls, dizziness and vertigo dominated, constituting $90 \%$ of the neurological causes. The remaining patients reported muscle weakness in lower limbs. Dizziness or vertigo is one of the most frequent complaints of individuals in older age. The etiology varies and is often difficult to determine. It can accompany the symptoms of orthostatic hypotension, or can be related to pharmacological treatment (levodopa, dopaminergic agonists, and others), but may also be the result of coexisting diseases: cerebral atherosclerosis, hypertension, vertebrobasilar circulation disturbances, etc. To eliminate the above- mentioned factors, in this study dizziness or vertigo was considered the direct cause of falls only if the attack of dizziness or vertigo occurred directly before the fall and the patient did not have falling blood pressure, did not take medicine which could decrease the blood pressure, and had no other symptoms suggesting more severe coexisting diseases.

In this study, environmental factors represented $12 \%$ of causes of falls. Although these factors occurred three times less often than in the control group, they should not be forgotten. Obstacles on the floor or thresholds are additional hazards for patients with PD and eliminating them from e.g. the patient's home can reduce the risk of falling.

Postural reflexes impairment was the cause of $10 \%$ of falls in this study. This type of fall occurs mostly during changes of the body position, when the patient is rising from a chair or bed. In the study of Willemsen $e t a l$. [21] the falls in PD were more frequently associated with postural instability than with environmental factors. In our study these two causes of falls occur with comparable frequency.

Orthostatic hypotension and severe dyskinesia are relatively rare causes of falls - in this study the frequency was $4.1 \%$ and $3.6 \%$, respectively. Although autonomic disorders occur in over $80 \%$ of patients with PD, the most common symptoms are constipation, salivation and seborrhea, and orthostatic hypotension is less frequent. In addition, after the orthostatic hypotension is diagnosed, there is a possibility of either pharmacological or non-pharmacological treatments of this symptom. Data from previously published studies concerning the importance of autonomic disorders, and especially orthostatic hypotension, are controversial. According to Koller et al. [22] the presence of orthostatic hypotonia does not significantly influence the frequency of falls, while according to Williams et al. [23] autonomic disorders are independent risk factors of falls.

Olanow et al. [14] claim that dyskinesia is a rare direct cause of falls. In a majority of patients until some stage of disease, they are mild and rather predictable (they originally occur mainly in an 'on' period). Mild dyskinesia is usually unable to cause a fall, but significantly more severe dyskinesia results in a bedridden lifestyle, in which falls may occur incidentally.

The classification of causes of falls proposed by Olanow et al. [14] was proved to be useful in our study. Only approximately $6 \%$ of falls could not be classified according to this classification. This is a relatively low percentage, which may be related to the clear criteria of the 
Olanow classification and prospective nature of the study, which caused the patients and their caregivers to be more inclined to define the circumstances and causes of falls.

Significantly worse results were obtained by analyzing the causes of falls by means of the frequently used classification by St. Louis [1], where unclassified falls constituted as many as $36.6 \%$. It probably results from the fact that this classification was designed for the general population of the elderly and not for patients with $\mathrm{PD}$ and does not take into account many causes of falls typical of this disease. It includes only four categories to which it is difficult to classify some falls typical of PD, for example, the most common sudden falls.

The St. Louis classification proved to be useful when comparing causes of falls in patients with PD and the control group. In the present study the most common causes of falls were intrinsic factors ( $43 \%$ of falls) among patients and in the control group both intrinsic and extrinsic factors were comparable (33.3\% vs. $35.6 \%$ ).

The most frequent consequence of falls was the fear of walking ( $38 \%$ of falls). A similar result was obtained by analyzing falls in the control group. Among the subjective consequences of falls in patients with $\mathrm{PD}$, the restrictions of physical activity for some period of time (3.6\%) were also recorded, which probably was a result of fear, despite the lack of awareness of this kind of feeling. For over $40 \%$ of patients, falls were therefore the cause of emotional disturbances and a decrease of physical activities.

Serious objective consequences of falls, such as hospitalization, need for a surgical intervention or immobilization of the limb due to fracture, occurred occasionally (4.6\% of falls). The most common objective consequences of falls were contusions, superficial wounds as well as joint dislocation (about 30\%). Similar results were obtained by other authors in prospective studies. According to Bloem et al. [4], 42\% of PD fallers sustained injuries within a year. In the study of Gray and Hildebrand [20], similarly to this study, about $40 \%$ of falls led to injuries, contusions and superficial wounds being the most frequent. In both studies, states that can lead to a life-threatening condition after falls were uncommon; in the study of Gray and Hildebrand [20] it was one fracture among the 118 analyzed falls, and in the study of Bloem et al. [4] it concerned $4 \%$ of patients with $\mathrm{PD}$.

The absolute number of adverse consequences of falls undoubtedly depends on the time of observation. According to the data published on the basis of a study of people over the age of 65 years, falls are the leading cause of death due to injury [24]. Sixty percent of deaths in people over 80 years of age are caused by brain damage due to injury after the fall [25]. Another $2.5 \%$ of subjects require hospitalization, and $20 \%$ use medical assistance [4]. According to the Web-based Injury Statistics Query and Reporting System [26] and the study of Cooper et al. [11] 3-5\% of falls end with fractures. It also concerns PD. Throughout the course of the disease, at least several percent of the patients are seriously threatened with the consequences of falls. In the study of Koller et al. [22], fractures of bones occurred in 13\% of patients during the course of disease, $18 \%$ of patients were hospitalized due to falls, and in $3 \%$ of patients falls led to the necessity of using a wheelchair.

The prospective nature of the study and only oneyear duration of observation could have influenced the number of adverse consequences of falls in this study. The patients reported at regular visits, during which the pharmacological treatment was modified, that they were made aware of the risk associated with falls. Furthermore, they were recommended to avoid a situation that threatens the patient with further falls (not going out during the 'off' period), which may have an impact not only on frequency, but also on the consequences of falls.

In the analysis of the consequences of falls it should be remembered that injuries of the body associated with falls are only the beginning of the cascade of subsequent possible complications. A consequence of falls in PD is femoral fractures, experienced by as many as $25 \%$ of patients after 10-year duration of the disease [27]. About every third sudden admission to hospital of a patient with PD is due to injury [28].

Several months immobilization associated with the limb fracture causes serious consequences, such as more severe osteoporosis and muscle weakness, that secondarily promote recurrent fractures. Immobilization is also the cause of higher risk of pneumonia, urinary tract infections, myocardial infarction and stroke. A bedridden patient is completely dependent on others, requiring care, physiotherapy and other additional socio-therapeutic solutions, which has a direct influence on the costs of treatment. For the prognosis of patients, it is therefore extremely important to determine the causes of falls to effectively prevent them in the subsequent years of the disease.

\section{Conclusions}

1. The most common causes of falls according to the Olanow et al. classification were sudden falls, followed by freezing and neurological signs. 
2. The most common causes of falls according to the St. Louis classification were intrinsic factors (mobility systems failure, impaired balance, sensory impairment, cognitive impairment).

3. One-third of falls caused body injuries, and $5 \%$ of falls required medical help including hospitalization.

\section{Acknowledgements}

This study was supported with a grant received from the State Committee of Research (grant no. 3PO5B. 020.25).

\section{Disclosure}

The authors report no conflict of interest.

\section{References}

1. Tinetti M.E., Baker D.I., McAvay G. A multifactorial intervention to reduce the risk of falling among elderly people living in the community. N Engl J Med 1994; 331: 821-826.

2. Lach H.W., Reed A.T., Arfken C.L., et al. Falls in the elderly: reliability of a classification system. J Am Geriatr Soc 1991; 39: 197-202.

3. Tinetti M.E., Williams T.F., Mayewski R. Fall risk index for elderly patients based on number of chronic disabilities. $A m$ J Med 1986; 80: 429-434.

4. Bloem B.R., Grimbergen Y., Cramer M. Prospective assessment of falls in Parkinson's disease. J Neurol 2001; 248: 950-958.

5. Wood B.H., Bilclough J.A., Bowron A., et al. Incidence and prediction of falls in Parkinson's disease: a prospective multidisciplinary study. J Neurol Neurosurg Psychiatry 2002; 72: 721-725.

6. Wielinski C.L., Erickson-Davis C., Wichmann R., et al. Falls and injuries resulting from falls among patients with Parkinson's disease and other parkinsonian syndromes. Mov Disord 2005; 20: 410-415.

7. Ashburn A., Fazakarley L., Ballinger C., et al. A randomised controlled trial of a home based exercise programme to reduce risk of falling among people with Parkinson's disease. J Neurol Neurosurg Psychiatry 2007; 78: 678-684.

8. Ebmeier K.P., Calder S.A., Crawford J.R. Mortality and causes of death in idiopathic Parkinson's disease: results from the Aberdeen whole population study. Scott Med J 1990; 35: 173-175.

9. Bennett D.A., Beckett L.A., Murray A.M. Prevalence of par kinsonian sings and associated mortality in a community population of older people. $N$ Engl J Med 1996; 334: 71-76.

10. Wenning G.K., Eberbach G., Verny M., et al. Progression of falls in postmortem - confined parkinsonian disorders. Mov Disord 1999; 12: 947-950

11. Cooper C., Campion G., Melton L.J. 3rd. Hip fractures in the elderly: a world-wide projection. Osteoporos Int 1992; 2: 285-289.
12. Donald I.P., Bulpitt C.J. The prognosis of falls in elderly people living at home. Age Ageing 1999; 28: 121-125.

13. Cryer C., Patel S. Falls, Fragility and Fractures-National Service Framework for older people: the case for and strategies to implement a joint Health Improvement and Modernisation Plan for Falls and Osteoporosis November 2001. http://www.laterlifetraining.co.uk/documents/fallsfragility_fractures.pdf.

14. Olanow C.W., Watts R.L., Koller W.C. An algorithm for the management of Parkinson's disease: treatment guidelines. Neurology 2001; 56 (11 Suppl 5): S1-S88.

15. Litvan I., Bhatia K.P., Burn D.J., et al. Movement Disorders Society Scientific Issues Committee report: SIC Task Force appraisal of clinical diagnostic criteria for Parkinsonian disorders. Mov Disord 2003; 18: 467-486.

16. Czarkowska H., Tutaj M., Rudzińska M., et al. Cardiac responses to orthostatic stress deteriorate in Parkinson disease patients who begin to fall. Neurol Neurochir Pol 2010; 44: 339-349.

17. Rudzińska M., Bukowczan S., Banaszkiewicz K., et al. Causes and risk factors in patients with Parkinson's disease. Neurol Neurochir Pol 2008; 42: 216-222.

18. Michałowska M., Krygowska-Wajs A., Jedynecka U., et al. Analysis of causes for falls in people with Parkinson's disease. Neurol Neurochir Pol 2002; 36: 57-68.

19. Hennerberg A.E., Scholl I., Kogan E. Myoclonic astatic attacks in patients suffering from Parkinson's disease. Eur J Neurol 1998; 5: 365-368.

20. Gray P., Hildebrand K. Fall risk factors in Parkinson's disease. J Neurosci Nurs 2000; 32: 222-228.

21. Willemsen M.D., Grimbergen Y.A., Slabbekoorn M., et al. Falling in Parkinson's disease: more often due to postural instability than to environmental factors. Ned Tijdschr Geneeskd 2000; 144: 2309-2314.

22. Koller W.C., Glatt S., Vetere-Overfield B., et al. Falls and Parkinson's disease. Clin Neuropharmacol 1989; 12: 98-105.

23. Williams D.R., Watt H.C., Lees A.J. Predictors of falls and fractures in bradykinetic rigid syndromes: a retrospective study. J Neurol Neurosurg Psychiatry 2006; 77: 468-473.

24. Stevens J.A., Adekoya V. Brain injury resulting from falls among elderly persons. JAMA 2001; 286: 2665.

25. Velozo C.A., Peterson E.W. Developing meaningful fear of falling measures for community dwelling elderly. Am J Phys Med Rehabil 2001; 80: 662-673.

26. CDC Web-based Injury Statistics Query and Reporting System (WISQARS) National Center for Injury Prevention and Control, Centers for Disease Control and prevention (producer). www.cdc.gov/ncipc/wisqars, 2001.

27. Johnell O., Melton I., Atkinson E.J. Fracture risk in patients with parkinsonism: a population based study in Olmsted County, Minnesota. Age Ageing 1992; 21: 32-38.

28. Guneysel O., Onultan O., Onur O. Parkinson's disease and the frequent reasons for emergency admission. Neuropsychiatr Dis Treat 2008; 4: 711-714. 